\title{
STRATEGI PENINGKATAN KESIAPAN APARATUR PEMERINTAH KOTA BOGOR DALAM IMPLEMENTASI SISTEM INFORMASI PENGELOAAN KEUANGAN DAERAH
}

\section{Improvement Employee-Readiness Strategy of Bogor City Goverment in Implementation of Local Financial Management Information System}

\author{
Sumaryanto ${ }^{1}$, A. Faroby Faletehan ${ }^{2}$, Dwi Rachmina ${ }^{3}$ \\ ${ }^{1}$ Staf Sekretariat Badan Kepegawaian dan Pengembangan Sumber Daya Aparatur (BKP-SDA) Kota Bogor. \\ Email: sumaryantoto@gmail.com \\ 2Staff Pengajar Departemen Ekonomi Sumberdaya dan Lingkungan. Fakultas Ekonomi dan Manajemen. IPB. \\ Email : robie_fa@yahoo.com \\ 32Staff Pengajar Departemen Agribisnis. Fakultas Ekonomi dan Manajemen. IPB. Email : \\ dwirachmina@gmail.com
}

\begin{abstract}
Utilization of information technology in all stages of local financial management becomes very important especially in the effort to bring out good governance. Local financial management must be implemented in an orderly manner and in accordance with law, efficient, effective, transparent, accountable and responsible with due regard to justice, compliance and benefit to the community. The purposes of this research were to analyze the stage of employee readyness in implementation of local financial management information system, to analyze the effectivity of local financial management information system in Goverment Internal Controlling System and to obtain the strategy improving employee-readiness of Bogor City goverment in implementation of local financial management information system. The data consisted of primary and secondary data. Primary data was obtained from direct observation, interview and questioners with stratified random sampling method. While the secondary data was obtained from literature and related documents. This study used rating scale analysis, and SWOT analysis. The Result of study showed that employee-readiness of Bogor City goverment in implementation of local financial manangement information system were on the ready criteria but still needed a little improvement, and local financial management information system were quite effective to assist financial management employee in Bogor City goverment in implementation of Goverment Internal Controlling System. The chosen strategy was to improve the development and capacity building of competencybased employees in local financial management.
\end{abstract}

Key words : employee-readiness, financial, information system, strategy.

ABSTRAK
Pemanfaatan teknologi informasi pada setiap tahapan pengelolaan keuangan daerah menjadi sangat
penting terutama dalam upaya mewujudkan tata kelola pemerintahan yang baik. Pengelolaan
keuangan daerah harus dilaksanakan scara tertib, sesuai dan taat tterhadap peraturan perundang-
undangan, sfektif, efisien, transparan, akuntabel, bertanggung jawab dengan memperhatikan
keadilan, kepatuhan dan bermanfaat bagi masyarakat. Penelitian ini bertujuan menganalisis tingkat
kesiapan aparatur dalam implementasi sistem informasi pengelolaan keuangan daerah di
Lingkungan Pemerintah Kota Bogor, menganalisis efektifitas sistem informasi pengelolaan
keuangan daearah dalam pelaksanaan Sistem Pengendalian Intern di Lingkungan Pemerintah Kota
Bogor dan merumuskan strategi yang dapat dilakukan untuk meningkatkan kesiapan aparatur
Pemerintah Kota Bogor dalam implementasi sistem informasi pengelolaan keuangan daerah. Data
yang digunakan adalah data primer dari dan data sekunder. Data primer diperoleh dari observasi,
wawancara dan kuesioner dengan metoda stratified random sampling. Sedangkan data skunder
diperoleh melalui literatur dan dokumen-dokumen terkait. Penelitian ini menggunakan analisis
rating scale dan analisis SWOT. Hasil penelitian menunjukan bahwa, kesiapan aparatur dalam
implementasi sistem informasi pengelolaan keuangan daerah secara keseluruhan berada pada
kriteria siap tetapi masih perlu peningkatan dan sistem informasi pengelolaan keuangan daerah
cukup efektif dalam penyelenggaraan sistem pengendalian intern pemerintah. Strategi yang terpilih


adalah peningkatan pembinaan dan pengembangan kapasitas aparatur pengguna sistem informasi pengelolaan keuangan daerah yang berbasis kompetensi.

Kata kunci: kesiapan aparatur, sistem informasi, pengelolan keuangan, strategi.

\section{PENDAHULUAN}

Pengelolaan keuangan daerah merupakan faktor penting di dalam penyelenggaraan pemerintahan dan pembangunan di daerah, karena hampir tidak ada kegiatan pemerintahan yang tidak membutuhkan biaya. Semakin besar jumlah uang yang tersedia, semakin banyak pula kemungkinan kegiatan atau pekerjaan yang dapat dilaksanakan. Demikian juga, semakin baik pengelolaan keuangan suatu daerah maka penggunaan dana atau uang di daerah tersebut akan semakin efektif dan efisien.

Menurut Permendagri No. 21 Tahun 2011, yang dimaksud dengan Keuangan Daerah adalah semua hak dan kewajiban daerah dalam rangka penyelenggaraan pemerintahan daerah yang dapat dinilai dengan uang termasuk didalamnya segala bentuk kekayaan yang berhubungan dengan hak dan kewajiban. Sementara pengelolaan keuangan daerah adalah keseluruhan kegiatan yang meliputi perencanaan, pelaksanaan, penatausahaan, pelaporan, pertanggung-jawaban, dan pengawasan keuangan daerah tersebut.

Pengelolaan keuangan daerah harus dilaksanakan secara tertib serta sesuai dan taat terhadap perundang-undangan, efisien, efektif, dan bertanggung jawab dengan memperhatikan keadilan, kepatuhan dan bermanfaat bagi masyarakat serta transparan dan akuntabel.

Dalam upaya meningkatkan transparansi dan akuntabilitas serta efisiensi dan efektifitas penyelenggaraan sistem pengelolaan keuangan daerah, pada awal tahun 2015 Pemerintah Kota Bogor mulai memanfaatkan Sistem Informasi Akuntansi dan Pelaporan yang dikembangkan oleh Satuan Tugas (Satgas)
Pengembangan Sistem Informasi Manajemen Daerah (SIMDA). Pemanfaatan SIMDA Keuangan sebagai sebuah implementasi kebijakan tidak akan efektif tanpa adanya dukungan dari Sumber Daya Manusia (SDM) yang cukup kualitas dan kuantitasnya. SDM sangat berpengaruh terhadap keberhasilan implementasi sebuah kebijakan, sebab tanpa kehandalan SDM implementasi kebijakan akan berjalan lambat.

Selain implementasi sistem informasi keuangan daerah atau SIMDA Keuangan, dalam rangka meningkatkan kinerja, transparansi, dan akuntabilitas pengelolaan keuangan daerah, pemerintah daerah juga diwajibkan untuk mengatur dan menyelenggarakan sistem pengendalian intern yang menyeluruh. Sistem Pengendalian Intern Pemerintah (SPIP) merupakan proses pengendalian secara integral dengan tindakan dan kegiatan manajemen penyelenggaraan pemerintah yang meliputi: perumusan kebijakan, perencanaan, penganggaran, pelaksanaan anggaran, pengelolaan anggaran, pelaporan, monitoring dan evaluasi, dimana proses pengendalian intern ini melibatkan pimpinan dan seluruh pegawai di lingkungan pemerintah daerah.

Salah satu temuan BPK yang tercantum dalam resume pemantauan tindak lanjut terhadap Laporan Keuangan Pemerintah Kota Bogor Tahun 2015 untuk jenis temuan Kelemahan Sistem Pengendalian Intern adalah bahwa "Penatausahaan Laporan Keuangan Pemerintah Kota Bogor Tahun 2015 Belum Memadai”. Hal tersebut disebabkan belum tersedianya sistem informasi akuntansi dan pelaporan, sehingga BPK merekomendasikan Walikota Bogor agar memerintahkan kepada BPKAD selaku entitas pelaporan 
dan para Kepala SKPD selaku entitas akuntansi untuk: 1) Menggunakan aplikasi SIMDA Keuangan versi akrual di seluruh SKPD, dan 2) Mempersiapkan kemampuan aparatur pengelola Laporan Keuangan pada SKPD dan BPKAD dalam menyusun laporan keuangan pemerintah daerah baik di tingkat entitas akuntansi maupun di tingkat entitas pelaporan melalui kegiatan pendidikan dan pelatihan.

Tujuan dari penelitian ini adalah : (1) Menganalisis tingkat kesiapan aparatur dalam implementasi Sistem Informasi Pengelolaan Keuangan Daearah. (2) Menganalisis efektifitas Sistem Informasi Pengelolaan Keuangan Daerah dalam pelaksanaan Sistem Pengendalian Intern Pemerintah. dan (3) Merumuskan strategi yang dapat dilakukan untuk meningkatkan kesiapan aparatur dalam implementasi Sistem Informasi Pengelolaan Keuangan Daerah.

\section{Ruang Lingkup Penelitian}

Ruang lingkup penelitian ini adalah merumuskan strategi untuk meningkatkan kesiapan aparatur Pemerintah Kota Bogor dalam implementasi Sistem Informasi Keuangan Daerah (SIPKD), sehingga diharapkan implementasi SIPKD dapat berjalan secara optimal dan meningkatkan kinerja keuangan Pemerintah Kota Bogor. Indikator atau dimensi kesiapan aparatur yang dimaksud dalam penelitian ini adalah dimensi kesiapan aparatur yang diadaptasi dari frame work Jung Yu Lai dan Chorng Shyong Ong (2010), yang terdiri dari 3 dimensi kesiapan aparatur yaitu: kesiapan teknologi aparatur (employee-technology readiness), kesiapan tupoksi aparatur (employee-task readiness), dan kesiapan struktural aparatur (employee-structure readiness).

Sedangkan yang dimaksud efektifitas Sistem Informasi Pengelolaan Keuangan Daerah dalam pelaksanan Sistem Pengendalian Intern Pemerintah (SPIP) dalam penelitian ini adalah sejauhmana aplikasi SIMDA Keuangan dapat membantu aparatur pengelola keuangan dalam pelaksanaan Sistem Pengendalian Intern di lingkungan Pemerintah Kota Bogor. Oleh karena itu sub unsur SPIP yang digunakan adalah sub unsur SPIP yang berkaitan dengan pengelolaan keuangan, yaitu: Review kinerja, Otoritas transaksi dan kejadian penting, Pencatatan yang akurat, Akuntabilitas pencatatan dan sumber daya, serta Pemantauan berkelanjutan.

\section{METODOLOGI}

\section{Lokasi dan waktu penelitian}

Penelitian ini dilaksanakan pada Satuan Kerja Perangkat Daerah (SKPD) di Lingkungan Pemerintahan Kota Bogor. Waktu Penelitian dilakukan selama 4 (empat) bulan yaitu dari bulan April sampai dengan Juli 2017.

\section{Metode pengumpulan data penelitian}

Jenis data dalam penelitian ini terdiri dari data primer dan data sekunder. Data primer, yaitu data yang diperoleh langsung dari sumbernya (sampel atau responden) melalui; observasi, wawancara langsung dan pengisian kuisioner oleh responden. Data sekunder berasal dari studi pustaka, dokumen dan kajian terhadap literatur terkait.

Sampel atau responden dalam penelitian ini adalah Operator SIMDA Keuangan pada setiap SKPD terdiri dari tiga orang yang masing-masing terdiri atas: satu orang Bendahara Pengeluaran, satu orang petugas Penatausahaan Laporan Keuangan, dan satu orang petugas Perencanaan Pelaporan. Dari jumlah populasi sejumlah 102 orang, dengan menggunakan rumus Slovin diperoleh besarnya sampel penelitian sebanyak 51 orang.

\section{Metode Analisis Data}

Alat analisis yang digunakan dalam penelitian ini adalah: (1) Analisis rating scale, (2) analisis SWOT.

Analisis rating scale dilakukan untuk mengukur tingkat kesiapan aparatur 
Pemerintah Kota Bogor dalam implementasi SIMDA Keuangan dan efektifitas Implementasi SIMDA Keuangan terhadap pelaksanan Sistem Pengendalian Intern Pemerintah. Menurut Riduwan (2010) dalam rating scale responden akan menjawab salah satu data kuantitatif yang telah disediakan. Analisis rating scale dilakukan melalui pengisian kuesioner oleh responden yang terdiri dari staf pejabat penatausahaaan keuangan SKPD, bendahara pengeluaran SKPD dan staf perencanaan dan pelaporan SKPD.

Total rata-rata seluruh nilai skor tingkat kesiapan aparatur dalam penelitian ini disajikan dalam bentuk skor berdasar pada kriteria kesiapan menurut Aydin dan Tasci (2005), (Tabel 1).

Tabel 1 Kriteria Tingkat Kesiapan Aparatur

\begin{tabular}{ll}
\hline \multicolumn{1}{c}{ Skor } & Kriteria Tingkat Kesiapan \\
\hline $1.00-$ & Tidak siap dan membutuhkan banyak \\
2.60 & tindakan \\
$2.61-$ & Tidak siap dan membutuhkan beberapa \\
3.40 & tindakan \\
$3.41-$ & Siap tetapi masih perlu ditingkatkan \\
4.20 & \\
$4.21-$ & Sangat siap \\
5.00 & \\
\hline
\end{tabular}

Sumber: Aydin dan Tasci (2005) dengan modifikasi

Sedangkan total rata-rata dari seluruh skor responden pada efektifitas implementasi SIMDA Keuangan terhadap pelaksanan Sistem Pengendalian Intern Pemerintah disajikan dalam bentuk kriteria skor (Tabel 2).

Analisis SWOT digunakan untuk mengidentifikasi dan menganalisis faktorfaktor strategis peluang (Opportunities) dan ancaman (Threats) yang dihadapi Pemerintah Kota Bogor dalam upaya peningkatan kesiapan aparatur Pemerintah Kota Bogor dalam implementasi Sistem Informasi Pengelolaan Keuangan Daerah dan dapat disesuaikan dengan kekuatan (Strengths) dan kelemahan (Weaknesess) yang ada. (Rangkuti, 2009).
Tabel 2 Kriteria Efektifitas Sistem Informasi Pengelolaan Keuangan Daerah terhadap Pelaksanaan SPIP

\begin{tabular}{cc}
\hline $\begin{array}{c}\text { Rasio } \\
\text { Efektifitas }\end{array}$ & Kriteria \\
\hline $0-39.99$ & Sangat tidak efektif \\
$40-59.99$ & Tidak efektif \\
$60-79.99$ & Efektif \\
$80-100$ & Sangat Efektif \\
\hline
\end{tabular}

Sumber: Litbang Depdagri (1991) dalam Yuniastari (2015)

Langkah-langkah perumusan strategi yang diperlukan adalah sebagai berikut:

1. Identifikasi Faktor Internal dan Eksternal

Perumusan strategi dimulai dengan kegiatan analisis situasional, yaitu proses untuk menemukan kesesuaian strategi antara peluang yang ada di lingkungan eksternal dengan kekuatan internal yang dimiliki sementara pada saat yang sama memperhitungkan berbagai ancaman yang ada di lingkungan luar dan kelemahan Internal.

2. Analisis Faktor Internal - Eksternal

Untuk menganalisis hasil identifikasi lingkungan maka digunakan matriks Evaluasi Faktor Internal (Internal Factor Evaluation/IFE) dan Evaluasi Faktor Eksternal (External Factor Evaluation/EFE) dengan memberikan bobot serta pengaruh masing-masing faktor internal (kekuatan dan kelemahan) dan faktor eksternal (peluang dan ancaman).

Penentuan bobot dilakukan dengan mengajukan identifikasi faktor internal dan eksternal kepada stakeholder dengan menggunakan metode paired comparison (Kinnear, 1991). Metode ini digunakan untuk memberikan penilaian terhadap bobot di setiap faktor-faktor internal dan eksternal.

Analisis matriks SWOT digunakan untuk merumuskan strategi dengan menggabungkan berbagai faktor yang terdapat dalam kekuatan, kelemahan, peluang dan ancaman. Matriks SWOT ini menggambarkan bagaimana peluang dan 
ancaman eksternal yang dihadapi dapat disesuaikan dengan kekuatan dan kelemahan yang dimiliki. Metode ini mengarah pada usaha pencerahan (brainstroming) untuk menciptakan strategi-strategi alternatif yang mungkin tidak pernah terpikirkan sebelumnya oleh institusi.

\section{HASIL DAN PEMBAHASAN}

\begin{tabular}{lcr} 
Kesiapan & Aparatur & dalam \\
Implementasi & \multicolumn{1}{c}{ Sistem } & Informasi \\
Pengelolaan Keuangan Daerah
\end{tabular}

\section{Kesiapan Aparatur pada Dimensi Teknologi}

Berdasakan pengukuran yang dilakukan terhadap responden, diperoleh skor total dari pengisian kuesioner pada keseluruhan item pertanyaan mengenai kesiapan aparatur pada dimensi teknologi dalam implementasi Sistem Informasi Pengelolaan Keuangan Daerah adalah 2273 (74.2 persen dari total skor maksimum yang bisa dicapai) atau 3.71 (skala Likert).

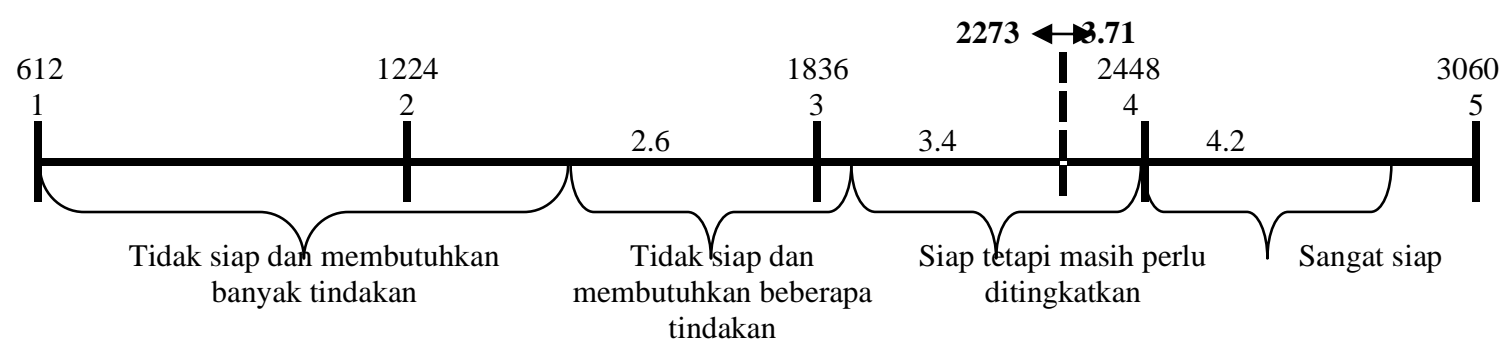

Gambar 1 Garis Kontinum Kesiapan Aparatur pada Dimensi Teknologi

Garis kontinum menunjukan bahwa kesiapan aparatur dalam implementasi Sistem Informasi Pengelolaan Keuangan Daerah dimensi teknologi berada pada kriteria siap tetapi masih perlu ditingkatkan. Artinya adalah bahwa Pemerintah Kota Bogor masih perlu meningkatan kesiapan aparaturnya pada dimensi teknologi agar implementasi Sistem Informasi Pengelolaan Keuangan Daerah dapat terlaksana menjadi lebih baik lagi.

\section{Kesiapan Aparatur pada Dimensi} Tugas Pokok dan Fungsi

Berdasakan hasil pengukuran, skor total kesiapan aparatur dalam implementasi Sistem Informasi Pengelolaan Keuangan Daerah pada dimensi tugas pokok dan fungsi adalah 1739 (75.8 persen dari total skor maksimum yang bisa dicapai) atau 3.79 (skala Likert).

Gambar 2 menunjukan bahwa skor kesiapan aparatur dalam implementasi Sistem Informasi Pengelolaan Keuangan Daerah pada dimensi tugas pokok dan fungsi berada pada kriteria siap tetapi masih perlu ditingkatkan. Hal ini menunjukan bahwa Pemerintah Kota Bogor masih perlu meningkatkan kesiapan aparaturnya pada dimensi tugas pokok dan fungsi agar implementasi Sistem Informasi Pengelolaan Keuangan Daerah dapat terlaksana menjadi lebih baik lagi.

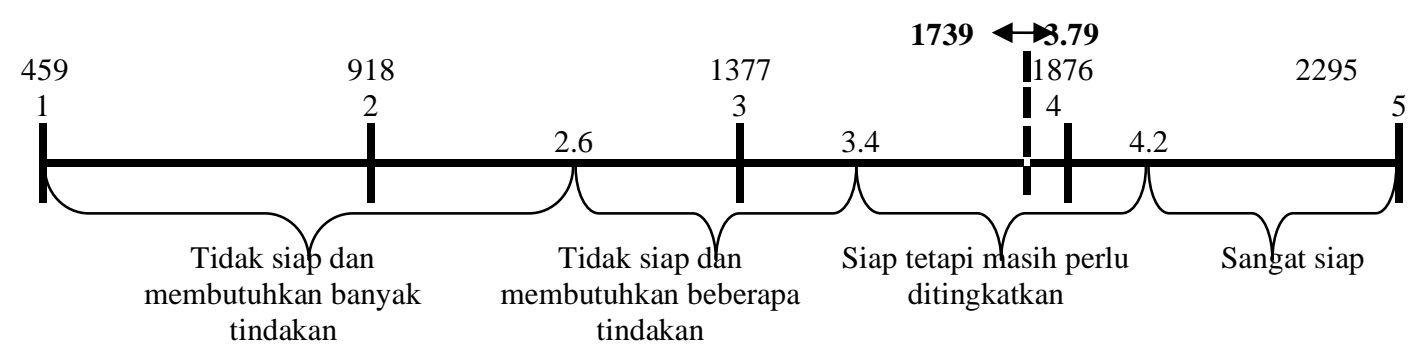

Gambar 2 Garis Kontinum Kesiapan Aparatur pada Dimensi Tugas Pokok dan Fungsi 


\section{Kesiapan Aparatur pada Dimensi Struktural}

Pengukuran kesiapan aparatur dalam implementasi Sistem Informasi Pengelolaan Keuangan Daerah pada dimensi struktural dilakukan terhadap responden yang terdiri dari 4 aspek yaitu ketidakkhawatiran kehilangan pekerjaan, ketidakkhawatiran bila terjadi rotasi, ketidakkhawatiran adanya pengaruh negatif dari aplikasi, dan ketidakkhawatiran posisi atau jabatan akan terganggu. Skor total yang diperoleh dari pengukuran kesiapan aparatur pada dimensi Struktural dalam Implementasi Sistem Informasi Pengelolaan Keuangan Daerah adalah 842 (83.2 persen dari total skor maksimum yang bisa dicapai) atau 4.16 (skala Likert).

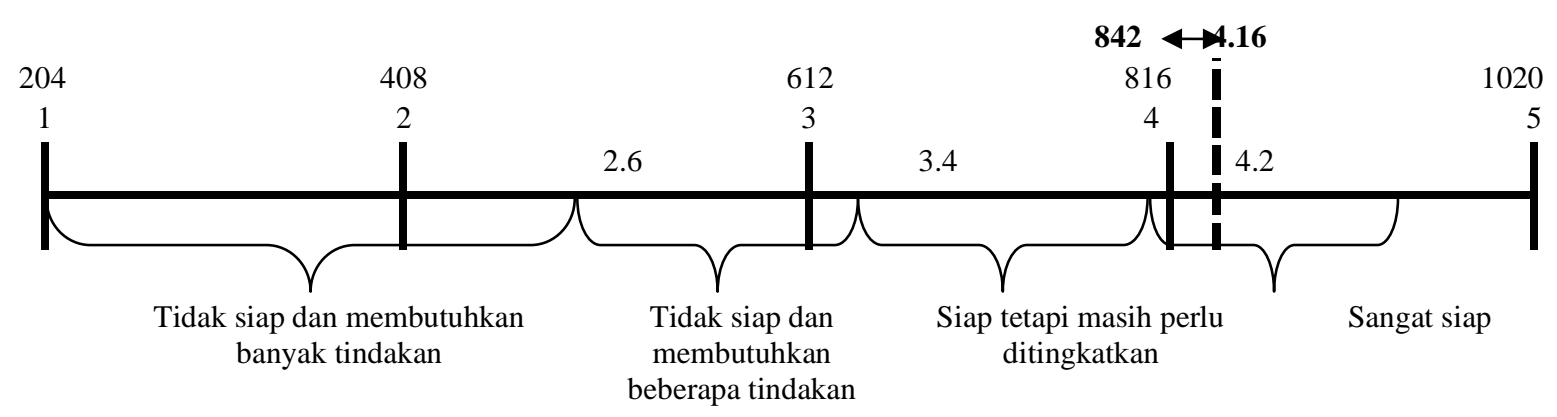

\section{Gambar 3 Garis Kontinum Kesiapan Aparatur pada Dimensi Struktural}

Garis kontinum sebagaimana tersaji pada Gambar 3, menunjukan bahwa kesiapan aparatur dalam implementasi Sistem Informasi Pengelolaan Keuangan Daerah pada dimensi struktural berada pada kriteria siap tetapi masih perlu ditingkatkan. Artinya bahwa Pemerintah Kota Bogor masih perlu meningkatkan kesiapan aparaturnya pada dimensi struktural agar implementasi Sistem
Informasi Pengelolaan Keuangan Daerah dapat terlaksana menjadi lebih baik lagi.

Dengan mengakumulasikan seluruh skor total dari ketiga dimensi kesiapan apatarur tersebut, skor total kesiapan aparatur dalam Implementasi Sistem Informasi Pengelolaan Keuangan Daerah secara keseluruhan adalah 4860 (76.2 persen dari total skor maksimum yang bisa dicapai) atau 3.81 (skala Likert).

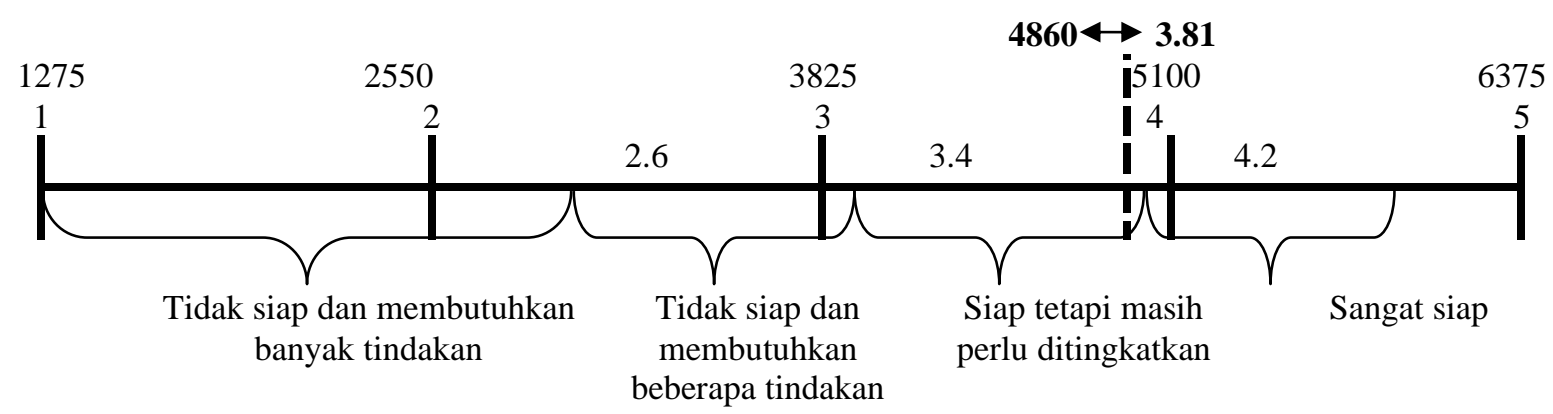

\section{Gambar 4 Garis Kontinum Kesiapan Aparatur dalam implementasi Sistem Informasi Pengelolaan Keuangan Daerah}

Garis kontinum yang tersaji pada Gambar 4 menunjukan bahwa kesiapan aparatur dalam implementasi Sistem Informasi Pengelolaan Keuangan Daerah berada pada kriteria siap tetapi masih perlu ditingkatkan. Hal ini menunjukan bahwa Pemerintah Kota Bogor masih perlu meningkatkan kesiapan aparaturnya agar implementasi Sistem Informasi 
Pengelolaan Keuangan Daerah dapat terlaksana menjadi lebih baik lagi.

\section{Efektifitas Sistem Informasi Pengelolaan Keuangan Daerah dalam Pelaksanaan Sistem Pengendalian Intern Pemerintah}

Skor total yang diperoleh pada pengukuran efektifitas Sistem Informasi Pengelolaan Keuangan Daerah dalam Pelaksanaan Sistem Pengendalian Intern Pemerintah adalah 1018 (79.84 persen dari total skor maksimum yang bisa dicapai) atau 3.99 (skala Likert).

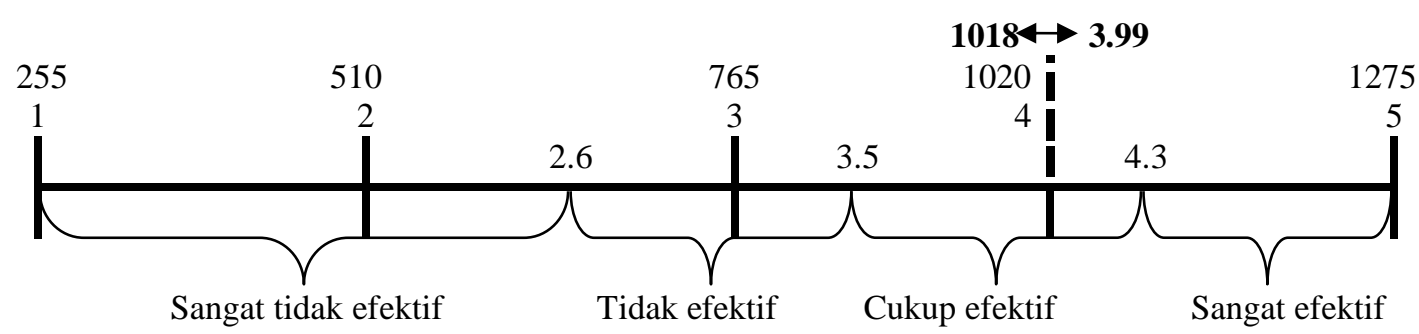

Gambar 5 Garis Kontinum Efektifitas SIMDA Keuangan dalam pelaksanaan SPIP

Garis kontinum yang tersaji pada Gambar 5 menunjukan Sistem Informasi Pengelolaan Keuangan Daerah cukup efektif membantu aparatur pengelola keuangan di Lingkungan Pemerintah Kota Bogor dalam pelaksanaan SPIP.

\section{Analisis Strategi}

Berdasarkan hasil penelitian kesiapan aparatur pemerintah Kota Bogor dalam implementasi Sistem Informasi Pengelolaan Keuangan Daerah, kemudian dilakukan identifikasi faktor-faktor internal maupun eksternal dalam peningkatan kesiapan aparatur dalam implementasi Sistem Informasi Pengelolaan Keuangan Daerah yang diperoleh melalui dokumen-dokumen, survey pendahuluan dan wawancara di lingkungan pemerintah Kota Bogor. Untuk analisis faktor internal digunakan matriks IFE (Internal Faktors Evaluation), sedangkan analisis faktor eksternal digunakan matriks faktor EFE
(External Factors Evaluatuion). Perumusan strategi dilakukan melalui analisis SWOT berdasarkan identifikasi isu strategis faktor internal dan eksternal seperti pada Tabel 3.

\section{Kekuatan (Strengths)}

1. Eksistensi Pemerintah Kota Bogor yang meraih BKD Award untuk kategori klaster 3 dari Pemerintah Provinsi Jawa Barat pada tahun 2015 dan 2016.

Prestasi berupa BKD Award untuk kategori klaster 3 dari Pemerintah Provinsi Jawa Barat pada tahun 2015 dan 2016 bagi pemerintah Kota Bogor merupakan wujud dari semangat pengelolaan aparatur dalam upaya mewujukan Tata Kelola Pemerintah yang bersih, efektif dan terpecaya. Penghargaan ini juga menunjukan bahwa pengelolaan aparatur di Lingkungan Pemerintah Kota Bogor sesuai dengan norma, standar, prosedur dan kriteria, serta inovatif. 


\section{Tabel 3 Matriks IFE dan EFE}

\section{Internal Factors Evaluation/IFE}

\section{FAKTOR INTERNAL}

\begin{tabular}{|c|c|}
\hline Kekuatan (Strengths) & Kelemahan (Weaknesess) \\
\hline $\begin{array}{l}\text { 1. Eksistensi BKPSDA Kota Bogor } \\
\text { 2. Dukungan Sistem dan Prosedur } \\
\text { Pengelolaan Sumber Daya Aparatur } \\
\text { (SDA) } \\
\text { 3. Memiliki Pengelola SDA yang } \\
\text { memadai } \\
\text { 4. Tingkat pendidikan pengguna SIMDA } \\
\text { Keuangan tergolong tinggi } \\
\text { 5. Tingkat keikutsertaan pengguna } \\
\text { SIMDA Keuangan yang cukup tinggi }\end{array}$ & $\begin{array}{l}\text { 1. Belum adanya Anjab sebagai dasar } \\
\text { perencanaan pengembangan kesiapan } \\
\text { SDA } \\
\text { 2. Mutasi/Rotasi/Perubahan SOPD terlalu } \\
\text { sering } \\
\text { 3. Lemahnya koordinasi } \\
\text { 4. Keterbatasan Sarana dan Prasaran diklat } \\
\text { 5. Minimnya prilaku aparatur yang } \\
\text { menunjukan semangat melayani, } \\
\text { mengayomi dan bersikap terbuka }\end{array}$ \\
\hline
\end{tabular}

\section{FAKTOR EKSTERNAL}

\begin{tabular}{lc}
\hline Peluang (Opportunities) & Ancaman (Threats) \\
\hline $\begin{array}{l}\text { 1. Rekomendasi BPK untuk } \\
\text { mengimplemtasikan SIMDA }\end{array}$ & $\begin{array}{l}\text { 1. Dampak negatif globalisasi terutama } \\
\text { arus informasi dan komunikasi }\end{array}$ \\
$\begin{array}{l}\text { Keuangan versi akrual } \\
\text { 2. Rekomendasi BPK untuk } \\
\text { mempersiapkan kemampuan aparatur } \\
\text { pengguna SIMDA Keuangan }\end{array}$ & $\begin{array}{l}\text { 2. Kurangnya komitmen pengembangan } \\
\text { dan peningkatan kesiapan aparatur } \\
\text { pengguna SIMDA Keuangan }\end{array}$ \\
$\begin{array}{l}\text { 3. Dukungan program-program diklat } \\
\begin{array}{l}\text { Sistem Informasi Pengelolaan } \\
\text { Keuangan Daerah }\end{array}\end{array}$ & $\begin{array}{l}\text { 3urangnya dukungan peraturan } \\
\text { perundang-undangan }\end{array}$ \\
$\begin{array}{l}\text { 4. Perkembangan dunia pada bidang } \\
\text { Teknologi Informasi }\end{array}$ & \\
$\begin{array}{l}\text { 5. Ketersedian layanan pengembang } \\
\text { aplikasi SIMDA Keuangan yaitu }\end{array}$ & \\
BPKP & \\
\hline
\end{tabular}

2. Dukungan Sistem dan Prosedur Pengelolaan Sumber Daya Aparatur Adanya sistem dan prosedur dalam pengelolaan sumber daya aparatur memberikan pemahaman terhadap aparatur mengenai tugas fungsi dan tanggung jawabnya, serta mempermudah aparatur dalam menyelesaikan tugas secara teratur dan tepat waktu.

3. Memiliki pengelola sumber daya aparatur yang memadai

Sumber daya aparatur adalah faktor sentral dalam suatu institusi/ organisai pemerintahan. Apapun bentuk serta tujuannya, organisasi pemerintahan dibuat berdasarkan visi untuk kepentingan aparatur dan dalam pelaksanaan misinya dikelola dan diurus oleh aparatur. Kondisi institusi akan sangat dipengaruhi dan tergantung pada kualitas serta kapasitas sumber daya apartur yang dimilikinya.

4. Tingkat pendidikan pengguna SIMDA Keuangan tergolong tinggi

Dengan semakin tingginya tingkat pendidikan aparatur, maka pengetahuan serta ilmu akademis aparatur akan semakin tinggi. Hal ini akan mengarahkan aparatur dengan 
pengetahuannya lebih berfokus pada pekerjaanya. Pola berfikir aparatur yang memiliki latar belakang pendidikan yang tinggi juga dapat meningkatkan produkivitas aparatur, yaitu apartur yang mampu menghasilkan sesuatu yang berguna terutama bagi instansi pemerintahan.

5. Tingkat keikutsertaan pengguna pada diklat Sistem Informasi Pengelolaan Keuangan Daerah yang cukup tinggi

Kinerja aparatur pengguna sistem informasi pengelolaan keuangan daerah akan menjadi lebih baik dengan penguasaan materi kerja yang lebih baik. Semakin banyak dan sering pengguna sistem informasi pengelolaan keuangan daerah mengikuti pelatihan atau bimbingan teknis, maka semakin baik pula penguasaan kerja aparatur.

\section{Kelemahan (Weaknesess)}

1. Belum adanya Analisis jabatan sebagai dasar perencanaan pengembangan kapasitas SDA

Analisis jabatan merupakan kegiatan pengumpulan, penilaian dan penyusunan informasi secara sistematis untuk mempelajari dan dan menyimpulkan keterangan atau faktafakta yang berkaitan dengan jabatan secara sistematis. Hal ini bertujuan untuk menciptakan kenyamanan dalam bekerja dan pengendalian pekerjaan pada suatu institusi pemerintahan. Analisis jabatan terdiri dari pengetahuan, keterampilan serta sikap apa saja yang harus dimiliki aparatur untuk mampu mengetahui dan melaksanakan tugas, wewenang dan tanggung jawabnya.

2. Mutasi aparatur yang terlalu sering

Mutasi atau rotasi aparatur adalah memindahkan posisi pekerjaan seorang aparatur dari tempat atau poisisi tertentu. Hal ini bukanlah sesuatu yang mudah, butuh waktu untuk menyesuaikan diri dan butuh waktu untuk mempelajari hal-hal yang berkaitan dengan pekerjaan baru yang belum ada atau belum dimiliki dalam pekerjaan lama seorang aparatur.

3. Lemahnya koordinasi

Lemahnya koordinasi antar SKPD terutama yang berkaitan dengan implementasi sistem informasi pengelolaan keuangan daerah menyebabkan kurang optimalnya kinerja terutama dalam upaya peningkatan kesiapan aparatur pengguna sistem informasi pengelolan keuangan daerah. Sedangkan keberhasilan pelaksanaan suatu pekerjaan atau tujuan organisasi akan sangat dipengaruhi oleh keberhasilan koordinasinya.

4. Sarana dan Prasarana penunjang diklat yang belum memadai

Sarana dan prasarana merupakan faktor penunjang kinerja pegawai yang cukup penting untuk dipenuhi karena terkait dengan aktivitas dan mobilitas kerja Badan Kepegawaian Pendidikan Sumber Daya Aparatur (BKP-SDA) selaku institusi pengelolaan aparatur pada Pemerintahan Kota Bogor. Saat ini, jumlah Sarana dan prasarana BKPSDA Kota Bogor masih kurang, salah satunya adalah belum tersedia sarana dan prasarana penunjang diklat, baik untuk diklat fungsional maupun diklat struktural. Hal ini merupakan salah satu kendala yang harus mendapat perhatian serius

5. Prilaku aparatur belum menunjukan semangat melayani, mengayomi dan bersikap terbuka

Aparat pemerintah adalah anggota masyarakat yang secara hukum dikukuhkan sebagai abdi negara yang bertanggung jawab atas dasar tugas dan wewenang yang telah diberikan sesuai bidang kemampuannya. Hal ini berarti bahwa, aparatur pemerintah wajib untuk selalu meningkatkan di bidangnya agar dapat bekerja secara profesional untuk melayani, mengayomi dan bersikap terbuka. Dengan profesionalisme diharapkan aparatur pemerintah mampu 
memberikan pelayanan yang cepat, tepat dan akurat sesuai dengan target dan sasaran yang dicanangkan.

\section{Peluang (Opportunities)}

1. Rekomendasi

BPK

untuk

mengimplementasikan

SIMDA

Keuangan versi akrual

BPK merupakan lembaga

pemeriksa keuangan negara yang kredibel dalam upaya mewujudkan tata kelola keuangan negara yang akuntabel dan transparan. Oleh karena itu segala bentuk rekomendasi BPK hendaknya ditindaklanjuti oleh setiap instansi pemerintah, salah satunya adalah rekomendasi untuk mengimplementasikan SIMDA Keuangan versi akrual kepada Pemerintah Kota Bogor.

2. Rekomendasi BPK untuk mempersiapkan kemampuan aparatur pengguna SIMDA Keuangan

Rekomendasi BPK berikutnya yang menjadi faktor peluang dalam upaya peningkatan kesiapan aparatur dalam implementasi sistem informasi pengelolaan keuangan daerah adalah bahwa Pemerintah Kota Bogor harus mempersiapkan kemampuan aparatur pengguna SIMDA Keuangan.

3. Program-program diklat SIMDA Keungan

Tujuan diselenggarakannya program pendidikan dan latihan (diklat) adalah untuk meningkatkan kompetensi teknis, manajerial, peningkatan efisiensi, efektifitas, dan kualitas pelaksanaan tugas aparatur. Oleh sebab itu keberadaan programprogram diklat SIMDA Keuangan yang diselenggarakan baik oleh lembaga maupun instansi pemerintah lain menjadi peluang dalam upaya peningkatan kesiapan apatatur dalam impementasi sistem informasi pengelolaan keuangan daerah.

4. Perkembangan dunia pada bidang Teknologi Informasi
Salah satu manfaat penggunaan teknologi informasi dalam pemerintahan adalah untuk mendukung pengelolaan pemerintahan yang lebih efektif dan efisien. Hal ini menjadikan teknologi informasi yang terus berkembang menjadi peluang yang baik dalam upaya peningkatan kesiapan apatatur dalam impementasi sistem informasi pengelolaan keuangan daerah

5. Layanan pengembang aplikasi SIMDA Keuangan dari BPKP

Dalam upaya peningkatan kepada shareholders dan stakeholders, Badan Pengawas Keuangan dan Pembangunan (BPKP) telah membentuk pusat layanan Sistem Informasi Manajemen Daerah (SIMDA). Adanya pusat layanan ini menjadi peluang yang baik dalam upaya peningkatan kesiapan apatatur dalam impementasi sistem informasi pengelolaan keuangan daerah.

\section{Ancaman (Threats)}

1. Dampak negatif globalisasi terutama arus informasi dan komunikasi

Semakin berkembangnya kemampuan masyarakat dalam penggunaan teknologi informasi dan semakin bebasnya masyarakat untuk mengakses situs pemerintah akan menjadi ancaman berupa cyber crime yang dapat merusak sistem informasi pengelolaan keuangan daerah.

2. Belum kuatnya komitmen pengembangan dan peningkatan kesiapan aparatur pengguna SIMDA Keuangan

Pengembangan dan peningkatan kesiapan aparatur merupakan upaya untuk meningkatkan efesiensi kerja serta produktifitas kinerja aparatur. Sehingga kuatnya komitmen baik dari lembaga maupun instasi pemerintah lain untuk pengembangan dan peningkatan kesiapan aparatur pengguna SIMDA Keuangan menjadi sangat penting. Apabila komitmen 
tersebut belum kuat, maka hal ini akan menjadi slah satu ancaman dalam upaya peningkatan kesiapan aparatur dalam impementasi sistem informasi pengelolaan keuangan daerah.

3. Peraturan perundang-undangan yang kurang mendukung

Peraturan perundang-undangan dibuat dengan tujuan untuk menjamin keseimbangan antara hak dan kewajiban, keseimbangan antara kewenangan dan kewajiban, serta memberikan pedoman dalam pelaksanaan tugas dan pekerjaan, dan menciptakan hubungan harmonis, aman dan dinamis untuk memajukan dan meningkatkan kesejahteraan. Kurangnya dukungan peraturan perundang-undangan akan menjadi salah satu ancaman atau hambatan dalam upaya peningkatan kesiapan apatatur dalam impementasi sistem informasi pengelolaan keuangan daerah.

\section{Identifikasi Faktor Kunci Eksternal dan Internal}

Wawancara terbuka dan penilaian dilakukan terhadap responden yang merupakan para pejabat esselon III pada Badan Kepegawaian dan Pengembangan Sumber Daya Aparatur (BKPSDA) Kota Bogor. (Tabel 4,5, 6 dan 7) menunjukan hasil penilaian responden atas faktorfaktor kekuatan, kelemahan, peluang dan ancaman yang mempengaruhi peningkatan kesiapan aparatur pengguna Sistem Informasi Pengelolaan Keuangan Daerah di Lingkungan Pemerintah Kota Bogor.

\section{Tabel 4 Hasil Penilaian Responden atas Faktor-faktor Kekuatan}

\begin{tabular}{|c|c|c|c|c|}
\hline No. & Strengths & Bobot & Rating & Skor \\
\hline 1 & $\begin{array}{l}\text { Eksistensi Pemerintah Kota Bogor yang meraih BKD } \\
\text { Award untuk kategori klaster } 3 \text { dari Pemerintah Provinsi } \\
\text { Jawa Barat pada tahun } 2015 \text { dan } 2016\end{array}$ & 0.138 & 3.50 & 0.481 \\
\hline 2 & $\begin{array}{l}\text { Dukungan Sistem dan Prosedur Pengelolaan Sumber } \\
\text { Daya Aparatur }\end{array}$ & 0.117 & 3.25 & 0.379 \\
\hline 3 & Memiliki pengelola sumber daya aparatur yang memadai & 0.133 & 3.50 & 0.467 \\
\hline 4 & $\begin{array}{l}\text { Tingkat pendidikan pengguna SIMDA Keuangan } \\
\text { tergolong tinggi }\end{array}$ & 0.106 & 3.25 & 0.343 \\
\hline 5 & $\begin{array}{l}\text { Tingkat keikutsertaan pengguna pada diklat Sistem } \\
\text { Informasi Pengelolaan Keuangan Daerah yang cukup } \\
\text { tinggi }\end{array}$ & 0.103 & 3.5 & 0.360 \\
\hline
\end{tabular}

Sumber: Data primer diolah (2017)

Tabel 5 Hasil Penilaian Responden atas Faktor-faktor Kelemahan

\begin{tabular}{clccc}
\hline No. & \multicolumn{1}{c}{ Weaknesess } & Bobot & Rating & Skor \\
\hline 1 & $\begin{array}{l}\text { Belum adanya Analisis jabatan sebagai dasar perencanaan } \\
\text { pengembangan kapasitas SDA }\end{array}$ & 0.074 & 1,75 & 0.129 \\
2 & Mutasi/Rotasi Pegawai & 0,999 & 1.50 & 0.148 \\
3 & Lemahnya koordinasi & 0.072 & 2.00 & 0.144 \\
4 & Sarana dan Prasarana diklat yang belum memadai & 0.075 & 1.50 & 0.113 \\
5 & $\begin{array}{l}\text { Belum sepenuhnya prilaku aparatur yang telah menunjukan } \\
\text { semangat melayani, mengayomi dan bersikap terbuka }\end{array}$ & 0.085 & 1.50 & 0.127 \\
\hline & Jumlah & & $\mathbf{0 . 6 6 1}$ \\
\hline
\end{tabular}

Sumber: Data primer diolah (2017) 
Tabel 6 Hasil Penilaian Responden atas Faktor-faktor Peluang

\begin{tabular}{clccc}
\hline No. & \multicolumn{1}{c}{ Opportunities } & Bobot & Rating & Skor \\
\hline 1 & $\begin{array}{l}\text { Rekomendasi BPK untuk mengimplemtasikan SIMDA } \\
\text { Keuangan versi akrual }\end{array}$ & 0.152 & 3.50 & 0.531 \\
2 & $\begin{array}{l}\text { Rekomendasi BPK untuk mempersiapkan kemampuan } \\
\text { aparatur pengguna SIMDA Keuangan }\end{array}$ & 0.154 & 2.75 & 0.424 \\
3 & $\begin{array}{l}\text { Program-program diklat SIMDA Keungan } \\
4\end{array}$ & 0.147 & 2.50 & 0.368 \\
5 & $\begin{array}{l}\text { Perkembangan dunia pada bidang Teknologi Informasi } \\
\text { BPKP pengembang aplikasi SIMDA Keuangan dari }\end{array}$ & 0.118 & 2.25 & 0.266 \\
\hline & Jumlah & & 2.75 & 0.295 \\
\hline
\end{tabular}

Sumber: Data primer diolah (2017)

Tabel 7 Hasil Penilaian Responden atas Faktor-faktor Ancaman

\begin{tabular}{llccc}
\hline No. & \multicolumn{1}{c}{ Threats } & Bobot & Rating & Skor \\
\hline 1 & $\begin{array}{l}\text { Dampak negatif globalisasi terutama arus informasi } \\
\text { dan komunikasi }\end{array}$ & 0.143 & 1.50 & 0.214 \\
2 & $\begin{array}{l}\text { Belum kuatnya komitmen pengembangan dan } \\
\text { peningkatan kapasitas aparatur pengguna SIMDA } \\
\text { Keuangan } \\
3\end{array}$ & 0.092 & 1.75 & 0.160 \\
& $\begin{array}{l}\text { Kurangnya dukungan Peraturan perundang-undangan } \\
\text { yang }\end{array}$ & 0.087 & 2.50 & 0.218 \\
\hline & Jumlah & & $\mathbf{0 . 5 9 2}$ \\
\hline
\end{tabular}

Sumber: Data primer diolah (2017)

\section{Strategi Peningkatan Kesiapan Aparatur Pemerintah Kota Bogor dalam Implementasi Sistem Informasi Pengelolaan Keuangan Daerah}

Berdasarkan kesimpulan analisis faktor-faktor internal dan eksternal kemudian disusun matriks SWOT utuk merumuskan strategi peningkatan kesiapan aparatur pemerintah Kota Bogor dalam implementasi sistem informasi pengelolaan keuangan daerah. Perumusan strategi ditunjukan pada Tabel 8.

\begin{tabular}{lcr}
\multicolumn{1}{c}{ Dalam } & $\begin{array}{c}\text { menyusun } \\
\text { peningkatan }\end{array}$ kapasitas & aparatur \\
Pemerintah & Kota Bogor & dalam \\
implementasi sistem informasi pengelolan
\end{tabular}

keuangan daerah, terdapat empat alternatif strategi yang dapat dilakukan, yaitu:

1. Strategi (SO); menggunakan kekuatan (Strengths) untuk memanfaatkan peluang (Opportunities) yaitu strategi peningkatan pembinaan dan pengembangan kapasiatas aparatur pengguna Sistem Informasi Pengelolaan Keuangan Daerah yang berbasis kompetensi.

2. Strategi (ST); menggunakan kekuatan (Strengths) untuk mengatasi ancaman/hambatan (Threats) yaitu strategi peningkatan koordinasi dan sinkronisasi dengan SKPD yang bertanggung jawab dalam pemanfaatan Sistem Informasi Pengelolaan Keuangan Daerah. 

Tabel 8 Matriks SWOT Peningkatan Kesiapan Aparatur Pemerintah Kota Bogor
dalam Implementasi Sistem Informasi Pengelolaan Keuangan Daerah

\begin{tabular}{|c|c|c|}
\hline & Kekuatan $(\mathrm{S})$ & Kelemahan (W) \\
\hline Eksternal & $\begin{array}{l}\text { 1. Eksistensi Pemerintah } \\
\text { Kota Bogor yang } \\
\text { meraih BKD Award } \\
\text { untuk kategori klaster } 3 \\
\text { dari Pemerintah } \\
\text { Provinsi Jawa Barat } \\
\text { pada tahun } 2015 \text { dan } \\
\text { 2016. } \\
\text { 2. Dukungan Sistem dan } \\
\text { Prosedur Pengelolaan } \\
\text { Sumber Daya Aparatur } \\
\text { (SDA) } \\
\text { 3. Memiliki Pengelola } \\
\text { SDA yang memadai } \\
\text { 4. Tingkat pendidikan } \\
\text { pengguna SIMDA } \\
\text { Keuangan tergolong } \\
\text { tinggi } \\
\text { 5. Tingkat keikut sertaan } \\
\text { pengguna SIMDA } \\
\text { Keuangan yang cukup } \\
\text { tinggi }\end{array}$ & $\begin{array}{l}\text { 1. Belum adanya Anjab } \\
\text { sebagai dasar perencanaan } \\
\text { pengembangan kesiapan } \\
\text { SDA } \\
\text { 2. Mutasi/Rotasi/ Pegawai } \\
\text { 3. Lemahnya koordinasi } \\
\text { 4. Keterbatasan Sarana dan } \\
\text { Prasaran diklat } \\
\text { 5. Minimnya prilaku aparatur } \\
\text { yang menunjukan } \\
\text { semangat melayani, } \\
\text { mengayomi dan bersikap } \\
\text { terbuka }\end{array}$ \\
\hline Peluang (O) & Strategi S-O & Strategi W-O \\
\hline $\begin{array}{l}\text { 1. Rekomendasi BPK untuk } \\
\text { mengimplemtasikan SIMDA } \\
\text { Keuangan versi akrual } \\
\text { 2. Rekomendasi BPK untuk } \\
\text { mempersiapkan kemampuan } \\
\text { aparatur pengguna SIMDA } \\
\text { Keuangan } \\
\text { 3. Tersedianya Program-program } \\
\text { diklat SIMDA Keungan oleh } \\
\text { lembaga pemerintah } \\
\text { 4. Perkembangan dunia pada } \\
\text { bidang Teknologi Informasi } \\
\text { 5. Tersedianya layanan dari } \\
\text { pengembangan aplikasi } \\
\text { SIMDA Keuangan }\end{array}$ & $\begin{array}{l}\text { Peningkatan pembinaan } \\
\text { dan pengembangan } \\
\text { kapasiatas aparatur } \\
\text { pengguna Sistem } \\
\text { Informasi Pengelolaan } \\
\text { Keuangan yeng berbasis } \\
\text { kompetensi. (S1, S2, S3, } \\
\text { O2, O3, O4, O5) }\end{array}$ & $\begin{array}{l}\text { Peningkatan koordinasi dan } \\
\text { sinkronisasi dengan SKPD } \\
\text { yang bertanggung jawab } \\
\text { dalam pemanfaatan Sistem } \\
\text { Informasi Pengelolaan } \\
\text { Keuangan Daerah (W1, W2, } \\
\text { W3, W4, W5, O2, O3,O5) }\end{array}$ \\
\hline Ancaman (T) & Strategi S-T & Strategi W-T \\
\hline $\begin{array}{l}\text { 1. Dampak negatif globalisasi } \\
\text { terutama arus informasi dan } \\
\text { komunikasi }\end{array}$ & $\begin{array}{l}\text { Penyusunan standar } \\
\text { kompetensi jabatan dan } \\
\text { pelaksanaan uji }\end{array}$ & $\begin{array}{l}\text { Penerapan prinsip-prinsip } \\
\text { analisis jabatan dalam } \\
\text { penataan aparatur pengguna }\end{array}$ \\
\hline $\begin{array}{l}\text { 2. Kurangnya komitmen } \\
\text { pengembangan dan } \\
\text { peningkatan kesiapan aparatur } \\
\text { pengguna SIMDA Keuangan }\end{array}$ & $\begin{array}{l}\text { kompetensi dalam rangka } \\
\text { peningkatan penataan } \\
\text { aparatur pengguna Sistem } \\
\text { Informasi Pengelolaan }\end{array}$ & $\begin{array}{l}\text { Sistem Informasi Pengelolaan } \\
\text { Keuangan Daerah (W1, W2, } \\
\text { W3, W4, W5, T1,T2,T3) }\end{array}$ \\
\hline $\begin{array}{l}\text { 3. Kurangnya dukungan } \\
\text { peraturan perundang- } \\
\text { undangan }\end{array}$ & $\begin{array}{l}\text { Keuangan Daerah (S1, S2, } \\
\text { S3, S4, T1, T2, T3) }\end{array}$ & \\
\hline
\end{tabular}


3. Strategi (WO); meminimalkan kelemahan (Weaknesess) dengan memanfaatkan peluang (Opportunities), yaitu strategi penyusunan standar kompetensi jabatan dan pelaksanaan uji kompetensi dalam rangka peningkatan penataan aparatur pengguna Sistem Informasi Pengelolaan Keuangan Daerah.

4. Strategi WT); meminimalkan kelemahan dan menghindari ancaman/ hambatan, yaitu strategi penerapan prinsip-prinsip analisis jabatan dalam penataan aparatur pengguna Sistem Informasi Pengelolaan Keuangan Daerah.

Berdasarkan selisih total pengaruh internal (kekuatan dan kelemahan) dan selisish total nilai pengaruh faktor eksternal (peluang dan ancaman/ hambatan) diperoleh nilai IFE sebesar 2.691 dan nilai EFE sebesar 2.476. Kedua nilai IFE dan EFE ini bernilai positif, yang berarti secara kumulatif faktor kekuatan lebih tinggi dibandingkan kelemahannya dan faktor peluang lebih tinggi dibandingkan dengan ancaman/hambatan yang mungkin muncul.

Dari hasil penilaian responden (narasumber) atas faktor-faktor internal dan eksternal yang mempengaruhi peningkatan kesiapan aparatur pengguna Sistem Informasi Pengelolaan Keuangan Daerah di Lingkungan Pemerintah Kota Bogor, kemudian disusun prioritas strategi berdasarkan kombinasi strategi yang memiliki (Tabel 9).

Tabel 9 Matriks Kombinasi Faktor faktor Internal dan Eksternal

\begin{tabular}{|c|c|c|}
\hline Eksternal Internal & $\begin{array}{l}\text { Strengths } \\
(2.030)\end{array}$ & $\begin{array}{c}\text { Weaknesess } \\
\text { (0.661) }\end{array}$ \\
\hline $\begin{array}{l}\text { Opportunities } \\
(1.884)\end{array}$ & $\begin{array}{l}\text { Strategi } \mathrm{S}-\mathrm{O} \\
\quad(3.914)\end{array}$ & $\begin{array}{c}\text { Strategi } \mathrm{W}-\mathrm{O} \\
(2.545)\end{array}$ \\
\hline $\begin{array}{l}\text { Threats } \\
(0.592)\end{array}$ & $\begin{array}{l}\text { Strategi } \mathrm{S}-\mathrm{T} \\
\quad(2.622)\end{array}$ & $\begin{array}{c}\text { Strategi } \mathrm{W}-\mathrm{T} \\
(1.253)\end{array}$ \\
\hline
\end{tabular}

Sumber: data primer diolah (2017)

Hasil kombinasi faktor-faktor internal dan eksternal yang mempengaruhi peningkatan kesiapan aparatur pengguna Sistem Informasi Pengelolaan Keuangan Daerah di Lingkungan Pemerintah Kota Bogor, menunjukan bahwa skor strategi kombinasi tertinggi adalah skor startegi Strengths - Opportunities (SO) dengan skor 3.914 atau berada pada kuadran I yang menurut Rangkuti (2009) kuadran tersebut merupakan situasi yang menguntungkan bagi Pemerintah Kota Bogor dalam upaya peningkatan kesiapan apaturnya dalam implementasi Sistem Informasi Pengelolaan Keuangan Daerah, sehingga strategi yang harus diterapkan dalam kondisi ini adalah mendukung kebijakan pertumbuhan yang agresif (growth oriented strategy).
Hasil kombinasi faktor-faktor internal dan eksternal yang mempengaruhi peningkatan kesiapan aparatur pengguna Sistem Informasi Pengelolaan Keuangan Daerah di Lingkungan Pemerintah Kota Bogor, menunjukan bahwa skor strategi kombinasi tertinggi adalah skor startegi Strengths - Opportunities (SO) dengan skor 3.914 atau berada pada kuadran I yang menurut Rangkuti (2009) kuadran tersebut merupakan situasi yang menguntungkan bagi Pemerintah Kota Bogor dalam upaya peningkatan kesiapan apaturnya dalam implementasi Sistem Informasi Pengelolaan Keuangan Daerah, sehingga strategi yang harus diterapkan dalam kondisi ini adalah mendukung kebijakan pertumbuhan yang agresif (growth oriented strategy). 
Strategi agresif dipilih dengan mengoptimalkan kekuatan untuk memanfaatkan peluang (Strategi S-O), yaitu peningkatan pembinaan dan pengembangan kapasitas aparatur pengguna Sistem Informasi Pengelolaan Keuangan yang berbasis kompetensi.

\section{Perencanaan Implementasi Strategi}

Untuk menindaklanjuti hasil kombinasi faktor-faktor internal dan eksternal yang mempengaruhi peningkatan kesiapan aparatur pengguna Sistem Informasi Pengelolaan Keuangan Daerah di Lingkungan Pemerintah Kota Bogor diperlukan perancangan program. Pelaksanan strategi terpilih tersebut disusun ke dalam bentuk pelaksanaan kebijakan yang lebih terperinci dan operasional dengan tujuan untuk mempermudah dan arahan pada proses pelaksanaan kebijakan tersebut. Bentuk pelaksanaan kebijan strategis tersebut adalah berupa rancangan program dan kegiatan (Tabel 10).

Tabel 10 Rancangan Program dan Kegiatan Peningkatan Kesiapan Aparatur dalam Implementasi Sistem Informasi Pengelolaan Keuangan Daerah

\begin{tabular}{|c|c|c|}
\hline Strategi & Program & Kegiatan \\
\hline \multirow{20}{*}{$\begin{array}{l}\text { Peningkatan pembinaan } \\
\text { dan pengembangan } \\
\text { kapasitas aparatur } \\
\text { pengguna Sistem } \\
\text { Informasi Pengelolaan } \\
\text { Keuangan yeng berbasis } \\
\text { kompetensi. }\end{array}$} & \multirow{9}{*}{$\begin{array}{l}\text { 1. Peningkatan } \\
\text { kapasitas sumber } \\
\text { daya aparatur }\end{array}$} & \multirow{2}{*}{$\begin{array}{ll}\text { 1. Pengembangan } & \text { Sumber Daya } \\
\text { Aparatur } & \text { Penatausahaan }\end{array}$} \\
\hline & & \\
\hline & & Keuangan SKPD \\
\hline & & 2. Diklat Peningkatan Kompetensi \\
\hline & & Penatausahaan \\
\hline & & Keuangan SKPD \\
\hline & & \multirow{3}{*}{$\begin{array}{l}\text { 3. Pengiriman Peserta Diklat } \\
\text { Penerapan Sistem Informasi } \\
\text { Pengelolaan Keuangan Daerah }\end{array}$} \\
\hline & & \\
\hline & & \\
\hline & \multirow{5}{*}{$\begin{array}{l}\text { 2. Pembinaan dan } \\
\text { pengembangan } \\
\text { aparatur }\end{array}$} & \multirow{4}{*}{$\begin{array}{ll}\text { 1. Sosialisasi } & \text { Peraturan } \\
\text { Penatausahaan } & \text { Keuangan } \\
\text { Daerah berbasis } & \text { Teknologi } \\
\text { Informasi } & \end{array}$} \\
\hline & & \\
\hline & & \\
\hline & & \\
\hline & & $\begin{array}{l}\text { 2. Penyusunan Anjab dan ABK } \\
\text { untuk jabatan fungsional umum } \\
\text { penatausahaan keuangan SKPD }\end{array}$ \\
\hline & 3. Peningkatan Sistem & \multirow{6}{*}{$\begin{array}{l}\text { 1. Monitoring Penilaian Kinerja } \\
\text { Aparatur Penatausahaan } \\
\text { Keuangan SKPD } \\
\text { 2. Fasilitasi alih tugas PNS antar } \\
\text { SKPD untuk memenuhi } \\
\text { kebutuhan pelaksanaan } \\
\text { penatausahaan keuangan SKPD }\end{array}$} \\
\hline & Pengawasan Internal & \\
\hline & dan Pengendalian & \\
\hline & Kebijakan & \\
\hline & & \\
\hline & & \\
\hline
\end{tabular}

\section{SIMPULAN DAN SARAN}

\section{Simpulan}

1. Salah satu upaya agar implementasi Sistem Informasi Pengelolaan Keuangan Daerah (SIPKD) di lingkungan Pemerintah Kota Bogor dapat terlaksana menjadi lebih baik lagi adalah dengan cara meningkatan kesiapan aparaturnya. Hasil penelitian menunjukan bahwa skor kesiapan aparatur dalam implementasi SIPKD berada pada kisaran skor $3.41-4.20$ dengan kriteria siap tetapi masih perlu peningkatan yaitu sebesar 3.81 (skala Likert kriteria Aydin dan Tasci)

2. Sistem Informasi Pengelolaan Keuangan Daerah secara cukup efektif 
dapat membantu pengelola keuangan dalam pelaksanaan SPIP. Skor total yang diperoleh pada pengukuran efektifitas Sistem Informasi Pengelolaan Keuangan Daerah dalam Pelaksanaan Sistem Pengendalian Intern Pemerintah adalah 3.99 (skala Likert kriteria Litbang Depdagri).

3. Upaya peningkatan kesiapan aparatur Pemerintah Kota Bogor dalam implementasi sistem informasi pengelolaan keuangan daerah dapat dicapai dengan strategi peningkatan pembinaan dan pengembangan kapasitas aparatur pengguna Sistem Informasi Pengelolaan Keuangan yang berbasis kompetensi. Strategi agresif ini dipilih dengan mengoptimalkan kekuatan untuk memanfaatkan peluang (Strategi S-O), karena memiliki skor kombinasi strategi tertinggi yaitu 3.914 $(\mathrm{ST}=2.62, \mathrm{WO}=2.54$ dan $\mathrm{WT}=1.25)$.

\section{Saran}

1. Melaksanakan seluruh kegiatan dari strategi yang sudah dirancang dengan konsisten serta melaksanakan pengelolaan keuangan daerah sesuai peraturan dan perundang-undangan dengan memanfaakan sistem informasi pengelolaan keuangan daerah yang terintegrasi.

2. Melakukan pembinaan maupun sosialisasi bagi pimpinan instansi SKPD mengenai pemahaman terhadap penyelenggaraan sistem pengendalian intern dalam pengelolaan keuangan daerah.

3. Meningkatkan koordinasi antar pimpinan SKPD, yaitu BKPSDA, DISKOMINFO dan BPKAD dalam implementasi sistem informasi pengelolaan keuangan daerah.

4. Mengalokasikan anggaran peningkatan tunjangan khusus pengelola laporan keuangan SKPD.

\section{DAFTAR PUSTAKA}

Aydin CH, Tasci D. 2005. Measuring Readiness for e-Learning: Reflections from an Emerging Country. Educational Technology \& Society, 8 (4), 244-257.

Kinnear TC, Taylor JR. 1991. Riset Pemasaran. Terjemahan. Jilid I. Erlangga, Jakarta.

Lai JY, Ong CS. 2010 Assesing and Managing Employees for Embracing Change: A MultipleItem Scale to Measure Employe Readines for E-Business. Technovation, 30, 76-85

Rangkuti F. 2009. Analisis SWOT Teknik Membedah Kasus Bisnis. Jakarta (ID): PT Gramedia Pustaka Utama.

Riduwan. 2010. Skala Pengukuran Variabel-variabel Penelitian. Bandung (ID): Alfabeta.

[KEMENDAGRI] Kementrian Dalam Negeri RI. 2011. Peraturan Menteri Dalam Negeri Nomor 21 Tahun 2011 tentang Perubahan Kedua atas Peraturan Menteri Dalam Negeri Nomor 13 tahun 2006 tentang Pedoman Pengelolaan Keuangan Daerah. Jakarta (ID): Kemendagri.

[BPKP] Badan Pengawas Keuangan dan Pembangunan RI. 2015. Satuan Tugas Pengembangan Sistem Informasi Daerah. System Requirement Aplikasi SIMDA Keuangan Versi 2.7. Pusdiklat Pengawasan BPKP. Bandung (ID): BPKP

Yuniastari SNLAK, Wiyati RK. 2015. Pengukuran Efektivitas dan Efisiensi Sistem e-research STIKOM Bali. Konferensi Nasional Sistem dan Informatika; Oktober 19-10; Bali, Indonesia. Bali (ID): STMIK STIKOM Oktober Bali. hlm 562-568. 